DOI https://doi.org/10.18551/rjoas.2017-11.07

\title{
THE PERFORMANCE OF INDONESIA INTERMEDIATE PROCESSED COCOA IN THE WORLD MARKET
}

\author{
Rahmawiliyanti ${ }^{1,2 *}$, Hanani Nuhfil ${ }^{3}$, Anindita Ratya $^{3}$, Syafrial $^{3}$ \\ ${ }^{1}$ Postgraduate Program in Agriculture Science, Agricultural Faculty, \\ University of Brawijaya, Indonesia \\ ${ }^{2}$ Department of Agribusiness, Agricultural Faculty, Wijaya Kusuma Surabaya University, \\ Indonesia \\ ${ }^{3}$ Department of Agribusiness, Faculty of Agriculture, University of Brawijaya, Indonesia
}

*E-mail: leni.ilma@yahoo.com

\begin{abstract}
The increasing consumption of chocolate and processed foods made from intermediate processed cocoa in the world communty, makes Indonesia more able to increase its role as one of the largest exporters of intermediate processed cocoa in the world market. In order to know what factors can increase intermediate cocoa exports, the purpose of this study are to analyze the factors that influence Indonesia's intermediate processed cocoa exports and know its competitiveness in the world market. The estimation method used is OLS and using SAS 9.1 .3 program with linear system procedure. It is found that cocoa butter and cocoa powder are partially influenced by cocoa beans export duty and respectively by lagged export of cocoa butter and lagged export of cocoa powder, while cocoa paste is significantly influenced by value added tax, export duty of cocoa beans and lagged export of cocoa paste. Cocoa paste, cocoa butter and cocoa powder of Indonesia has a comparative advantage that has the ability to compete in the world market.
\end{abstract}

\section{KEY WORDS}

Export, cocoa paste, cocoa butter, cocoa powder, competitiveness.

The downstream industries development of chocolate and processed foods made from intermediate processed cocoa have increased over time. In the last six years, from 2010 to 2016, world exports of these commodities showed an increase, especially in 2013 and 2016 at $8.61 \%$ and $7.33 \%$ from the previous year. The increasing export of downstream industrial products implicitly indicates the increasing consumption of chocolate and processed foods made from intermediate cocoa. The increasing production of downstream industries is an opportunity for Indonesia to be able more role as a supplier of raw materials of downstream industry production in the world market.

Indonesia has an advantage on the endowment, namely cocoa beans. Cocoa plants are well suited to grow in areas with tropical climates as Indonesia has. This wealth is Indonesia's capital to become one of the world's largest intermediate processed cocoa exporters in the world besides Germany, Belgium, Netherlands, Canada and the United States. This condition is in accordance with Heckscher-Ohlin theory which states that a country with abundant availability of production factor can make the country's processed cocoa price able to compete in the world market (Salvatore D, 2014). The policy in 2010 restricting the export of cocoa beans to fulfill the demand of domestic processed cocoa industry further strengthens Indonesia to compete with exporters of intermediate processed cocoa in the world market.( Ministry of Finance, 2012)

Exports of Indonesia intermediate processed cocoa are cocoa pasta, cocoa butter and cocoa powder which show the increasing year by year. In 2009, a year before enactment the export restriction on cocoa beans, cocoa pasta, cocoa butter and cocoa powder were 13,393 tons, 41,606 tons and 27,540 tons respectively. There were a significant increase for these products to 20,014 tons, 46,687 tons and 36,354 tons in 2010. The increase of those products takes place every year. In 2015 , it was 113,705 tons, 75,000 tons and 58,941 tons 
respectively. Indonesia can be a strong competitor of Netherlands which is an exporting country of intermediate processed cocoa although Netherlands does not have the resources to be able to cultivate cocoa crops. Netherlands must import to be able to produce intermediate processed cocoa. The increase of Indonesia intermediate processed cocoa exports should be improved even more so that Indonesia can become the main exporter of intermediate processed cocoa in the world. Therefore, it is necessary to study the factors affecting intermediate cocoa exports and their competitiveness in the world market.

There are variations of independent variables that affect the export of a commodity in a study previous. Chileshe (2005) stated that input costs, the lagged price of coffee, real exchange rate, the lagged price of cotton had a significant effect on coffee exports per capita. A positive rise in the lagged price of coffee would lead to a slight increase the volume of coffee exports. The decline in input prices and the price of cotton causes the export volume of coffee was increasing. Depreciation of exchange rate would increase the competitiveness of Zambian coffee.

According to Hameed Abdel A.A. et al (2009) in his research, the factors affecting Malaysian cocoa exports were determined significantly by real effective exchange rates, while industrial indices of developed countries and world cocoa prices were insignificant. It was different for Malaysian black pepper commodity; the research results of Kiong W.S. et al (2010) stated that commodity exports were mainly influenced by international black pepper price, domestic black pepper production, black pepper stock, steam sterilization plant in MPB, changes in tastes and preferences of consumers in pepper importing countries.

The determinants of cocoa exports in Nigeria, according to Nwachukwu I.N. et al in 2010 was the world export volume, exchange rate and the production of Nigerian cocoa. Nwachukwu recommends that priority should be given to the rehabilitation of old cocoa gardens and create new plantations in order to maintain the level of output. Verter N. (2016) in his research showed that cocoa beans production, world cocoa price, trade openness and exchange rate had a positive effect on export performance of cocoa beans in Cote D'Ivoire.

Faustino B. (2011) stated that the real effective exchange rate was negatively correlated with the export volume of coffee with the elasticity of -2.164 . International coffee prices had a positive and significant effect on the export volume of coffee with a price elasticity of 0.789 , however, the real interest rate, gross domestic product and gross capital formation were statistically insignificant in the short term. The increase in international coffee prices and gross domestic product increasing coffee export volume while the depreciation of the real effective exchange rate and the rise in real interest rates decreased the volume of coffee exports.

Based on the problems that have been stated, the purpose of this study is to analyze the factors that affect the export of Indonesia intermediate processed cocoa and know its competitiveness in the world market.

\section{METHODS OF RESEARCH}

This study uses secondary data in time series from 1992 to 2015 consisting of data related to export and intermediate processed cocoa competitiveness, namely cocoa butter, cocoa pasta and cocoa powder. Data sources are from Trademap, FAO, UN Comtrade, World Bank, BPS, Ministry of Finance, Directorate General of Plantation, and Coffee and Cocoa Research Center.

The measurement of the competitiveness of Indonesian intermediate processed cocoa uses Balassa Index which emphasizes measurement on the actual export value. The actual export flow represents a strong sector of a country known as the Revealed Comparative Advantage:

$$
\operatorname{RCA}_{i j}=\frac{\mathbf{X}_{\mathrm{ij}} / \sum_{\mathbf{i}} \mathbf{X}_{\mathrm{ij}}}{\sum_{\mathbf{j}} \mathbf{X}_{\mathrm{ij}} / \sum_{\mathbf{i} \mathbf{j}} \mathbf{X}_{\mathrm{ij}}}
$$


If the RCA index is greater than one (RCA> 1), then intermediate processed cocoa has a comparative advantage or export competitiveness. The opposite happen, if RCA is smaller than one $(R C A<1)$. If the RCA index is equal to one $(R C A=1)$, the Indonesian intermediate processed cocoa can be exported and may not be exported. The greater the value of the RCA index, the higher the level of comparative advantage. (Kagochi, 2007)

SAS version 9.1 .3 is used to analyze the factors that affect the exports of cocoa butter, cocoa paste and cocoa powder arranged in equations 1, 2 and 3 . The equations are expected respectively to be influenced by world prices, production and demand of each processed cocoa, processed cocoa export from competing countries, rupiah exchange rate against US dollar, dummy of cocoa policy (ppn and export duty) and processed cocoa export the previous year. The exporting countries of cocoa pasta (cp) and cocoa butter (cb) are Netherlands and Ivory Coast, while for cocoa powder (cpd) is Netherlands and Malaysia.

$$
\begin{aligned}
& X c p_{\text {Ina }}=a o+a_{1} P c p_{W}+a_{2} Q c p_{\text {Ina }}+a_{3} D c p_{\text {Ina }}+a_{4} X_{c p_{\text {Bld }}}+a_{5} X_{c p_{P G}}+a_{6} E_{\text {Ina }}+a_{7} D p p n+a_{8} D b k+ \\
& a_{9} X_{c P_{\text {Inat }-1}}+U_{5} \\
& \mathrm{Xcb}_{\text {Ina }}=\mathrm{bo}+\mathrm{b}_{1} \mathrm{Pcb}_{\mathrm{W}}+\mathrm{b}_{2} \mathrm{Qcb}_{\text {Ina }}+\mathrm{b}_{3} \mathrm{Dcb}_{\text {Ina }}+\mathrm{b}_{4} \mathrm{Xcb}_{\mathrm{Bld}}+\mathrm{b}_{5} \mathrm{Xcb}_{\mathrm{PG}}+\mathrm{b}_{6} \mathrm{Er}_{\text {Ina }}+\mathrm{b}_{7} \mathrm{Dppn}+\mathrm{b}_{8} \mathrm{Dbk}+ \\
& \mathrm{b}_{9} \mathrm{Xcb}_{\text {Inat }-1}+\mathrm{U}_{4} \\
& \mathrm{Xcpd}_{\text {Ina }}=c 0+\mathrm{c}_{1} \mathrm{Pcpd}_{\mathrm{W}}+\mathrm{c}_{2} \mathrm{Qcpd}_{\text {Ina }}+\mathrm{c}_{3} \mathrm{Dcpd}_{\text {Ina }}+\mathrm{c}_{4} \mathrm{Xcpd}_{\mathrm{Bld}}+\mathrm{C}_{5} \mathrm{Xcpd}_{\text {Mly }}+\mathrm{C}_{6} \mathrm{Er}_{\text {Ina }}+\mathrm{c}_{7} \mathrm{Dppn}+\mathrm{c}_{8} \mathrm{Dbk}+ \\
& \mathrm{C}_{9} \mathrm{Xcpd}_{\text {Inat-1 }}+\mathrm{U}_{6}
\end{aligned}
$$

Where:

$\mathrm{Xcp}_{\mathrm{Ina}}$ is Indonesia export of cocoa paste;

Pcp is world price of cocoa paste;

Qcp Ina is production of Indonesia cocoa paste;

Dcp Ina is Demand of Indonesia cocoa paste;

$\mathrm{Xcp}_{\mathrm{Bld}}$ is Nederland export of cocoa paste;

$\mathrm{Xcp}_{\mathrm{PG}}$ is Ivory Coast export of cocoa paste;

$\mathrm{Er}_{\text {Ina }}$ is exchange rate of Indonesia;

Dppn is dummy of value added tax;

Dbk is Dummy of Cocoa Beans Export Duty;

$\mathrm{Xcb}_{\text {Inat- } 1}$ is the lagged export of cocoa paste;

$\mathrm{Xcb}_{\text {Ina }}$ is Indonesia export of cocoa butter;

$\mathrm{Pcb}_{\mathrm{W}}$ is world price of cocoa butter;

$\mathrm{Qcb}_{\text {Ina }}$ is production of Indonesia cocoa butter;

Dcb Ina $_{\text {Is }}$ Demand of Indonesia cocoa butter;

$\mathrm{Xcb}_{\mathrm{Bld}}$ is Nederland export of cocoa butter;

$\mathrm{Xcb}_{\mathrm{PG}}$ is Ivory Coast export of cocoa butter;

$\mathrm{Er}_{\text {Ina }}$ is exchange rate of Indonesia;

$\mathrm{Xcb}_{\text {Inat-1 }}$ is the lagged export of cocoa butter;

$\mathrm{Xcpd}_{\text {Ina }}$ is Indonesia export of cocoa powder;

$\mathrm{Pcp}_{\mathrm{w}}$ is world price of cocoa powder;

$\mathrm{Qcpd}_{\text {Ina }}$ is production of Indonesia cocoa powder;

$\mathrm{Dcb}_{\text {Ina }}$ is Demand of Indonesia cocoa powder;

$\mathrm{Xcb}_{\mathrm{Bld}}$ is Nederland export of cocoa powder;

$\mathrm{Xcb}_{\mathrm{MIy}}$ is Malaysia export of cocoa powder;

$\mathrm{Er}_{\text {Ina }}$ is exchange rate of Indonesia;

$\mathrm{Xcpd}_{\mathrm{Inat}-1}$ is the lagged export of cocoa powder.

\section{RESULTS AND DISCUSSION}

Exports of cocoa butter, cocoa paste and cocoa powder show an improvement as can be seen in Figure 1, especially after 2010, after the enactment the regulation of Finance Minister. Regulation of the Minister of Finance No. 67 / PMK.011 / 2010 limits the export of cocoa beans to fullfil the needs of cocoa beans in the domestic intermediate processed cocoa industry. It indicates that Indonesia intermediate processed cocoa has an opportunity to improve the performance of cocoa market in the world. 


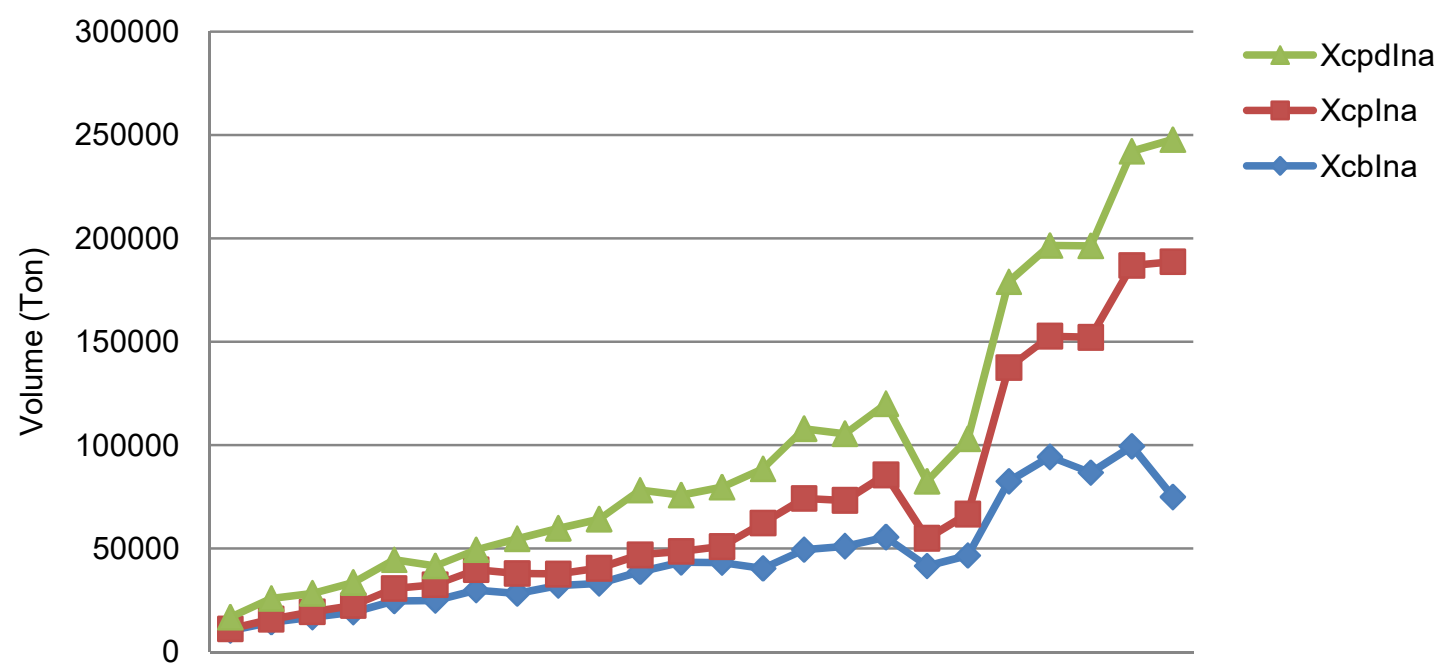

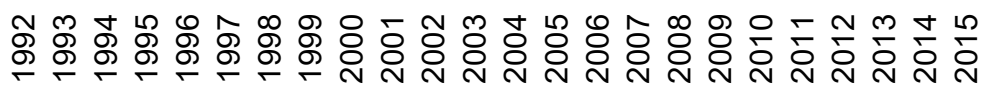

Figure 1 - Export of Cocoa Butter, Cocoa Pasta \& Cocoa Powder

The result of statistic test with linear system procedure can be seen in tables 1,2 and 3. Cocoa paste exports have $\mathrm{R}^{2}$ as big as $95.19 \%$. It means that exogenous variables used in the model have the opportunity to explain the variation of endogenous variables (Indonesian cocoa paste exports) as big as $95.19 \%$ and the rest of $4.81 \%$ influenced by other variables which is not included in the model.

Table 1 - Parameter Estimates of Cocoa Paste Export

\begin{tabular}{|l|c|c|c|}
\hline \multicolumn{1}{|c|}{ Variable } & Coefficient & t-Value & Significant \\
\hline Intercept & -6315.53 & -0.57 & 0.5778 \\
\hline World cocoa-paste price & 3.561258 & 0.97 & 0.3507 \\
\hline Indonesia cocoa-paste price & -0.90405 & -0.24 & 0.8129 \\
\hline Netherland cocoa-paste export & -0.12595 & -0.83 & 0.4219 \\
\hline Cote d'Ivoire cocoa-paste export & 0.127951 & 1.22 & 0.2441 \\
\hline Dummy of value added tax & -22298.1 & -2.06 & 0.0588 \\
\hline Dummy of Cocoa Beans Export Duty & 34108.29 & 2.91 & 0.0115 \\
\hline The lagged export of cocoa-paste & 0.917234 & 6.06 & $<.0001$ \\
\hline F Value = 39.57 (Sig. <0.0001) & & \\
R square = 0.95189 & & & \\
\hline
\end{tabular}

It is obtained F-value as big as 39.57 and the error rate less than $0.01 \%$. This shows that Indonesia cocoa paste export simultaneously with confidence level near $100 \%$ influenced by world cocoa-paste price, Indonesia cocoa-paste price, Netherland cocoa-paste export, Cote d'Ivoire cocoa-paste export, rupiah exchange rate against US dollar, value added tax and the lagged export of cocoa paste.

Partially, cocoa paste is significantly influenced by cocoa beans export duty, and the lagged export of cocoa paste and value added tax. This is because cocoa paste is the first intermediate processed cocoa product produced from cocoa beans. The next process is to process cocoa paste into cocoa butter and cocoa powder, so cocoa paste is subjected value added tax. The coefficient of the lagged export of cocoa paste has a positive sign and this sign corresponds to the theory, meaning that the presence of the lagged export of cocoa paste is used as a consideration to decide the volume of cocoa paste export on the current year.

The export duty of cocoa beans has a significant effect on the cocoa paste export. The availability of cocoa beans as a raw material is very important for intermediate processed cocoa industry. The positive sign on the coefficient means that the export duty of cocoa beans is made to support the development of domestic processed cocoa industry and the 
increasing acceptance of added value from cocoa beans. The quantity volume of the lagged export of cocoa paste as a form of caution and consideration to decide the current volume of cocoa paste export.

The result of statistical test analysis with linear system procedure in table 2 illustrates that cocoa butter exports have $\mathrm{R}^{2}$ of $90.26 \%$. It means that exogenous variables used in the model have the opportunity to explain the variation of endogenous variables (cocoa butter export) of $90.26 \%$ and the remaining $4.81 \%$ is influenced by other variables not included in the model.

The model has a F-value as big as 16.22 with an error rate of less than $0.01 \%$. This indicates that Indonesian cocoa butter export simultaneously with near confidence level as $100 \%$ influenced by cocoa butter price of the world, domestic cocoa butter (and cocoa powder) price, cocoa butter export of countries competitors, rupiah exchange rate against US dollar, value added tax and export volume of lagged export of cocoa paste.

Table 2 - Parameter Estimates of Cocoa Butter Export

\begin{tabular}{|l|c|c|c|}
\hline \multicolumn{1}{|c|}{ Variable } & Coefficient & t-Value & Significant \\
\hline Intercept & -10247.6 & -0.48 & 0.6375 \\
\hline World cocoa-butter price & 3.561390 & 0.34 & 0.7355 \\
\hline Indonesia cocoa-butter price & -4.90976 & -0.56 & 0.5840 \\
\hline Netherland cocoa-butter export & 0.140739 & 0.84 & 0.4140 \\
\hline Cote d'Ivoire cocoa-butter export & 0.165908 & 0.54 & 0.6006 \\
\hline Exchange Rate Indonesia & 0.132282 & 0.11 & 0.9132 \\
\hline Dummy of value added tax & -7161.55 & -0.58 & 0.5680 \\
\hline Dummy of Cocoa Beans Export Duty & 22786.66 & 1.82 & 0.0898 \\
\hline The lagged export of cocoa butter & 0.474043 & 2.06 & 0.0586 \\
\hline F Value = 16.22 (Sig. <0.0001) & & \\
R square = 0.90264 & & \\
\hline
\end{tabular}

Partially cocoa butter export is influenced by cocoa beans export duty and the lagged export of cocoa butter. The export duty of cocoa beans has a significant effect on the cocoa butter export. It is like in cacao paste industry, the availability of cocoa beans as raw material is very important for the cocoa butter industry. The positive sign on the coefficient means that the export duty of cocoa beans strongly supports the development of cacao butter industry.

The volume of the lagged export of cocoa butter affects the cocoa powder export of the year. This is an evaluation from the result of the lagged export of cocoa butter and used as a consideration to decide the export volume of cocoa butter in this year.

Table 3 - Parameter Estimates of Cocoa Powder Export

\begin{tabular}{|l|c|c|c|}
\hline \multicolumn{1}{|c|}{ Variable } & Coefficient & t-Value & Significant \\
\hline Intercept & -7406.49 & -1.12 & 0.2820 \\
\hline Ratio World cocoa-powder price and the lagged price of cocoa powder & 2525.721 & 0.76 & 0.4604 \\
\hline Indonesia cocoa-powder price & -2.36111 & -1.44 & 0.1741 \\
\hline Netherland cocoa-powder export & 0.056616 & 1.57 & 0.1405 \\
\hline Malaysia cocoa-butter export & 0.002398 & 0.06 & 0.9543 \\
\hline Exchange Rate Indonesia & 0.400682 & 1.01 & 0.3328 \\
\hline Dummy of value added tax & -5880.46 & -1.55 & 0.1445 \\
\hline Dummy of cocoa beans export duty & 15972.39 & 3.97 & 0.0016 \\
\hline The lagged export of cocoa powder & 0.737421 & 5.35 & 0.0001 \\
\hline F Value $=46.22$ (Sig. $<.0001)$ & & \multicolumn{3}{l}{} \\
R square $=0.96604$ & & \multicolumn{2}{l}{} \\
\hline
\end{tabular}

The result of statistical test analysis with linear system procedure in table 3 illustrates that cocoa powder export have $\mathrm{R}^{2}$ of $96.60 \%$. It means that the exogenous variables used in the model have the opportunity to explain the variation of Indonesian cocoa powder variable of $96.60 \%$ and the rest of $3.40 \%$ is influenced by other variables not included in the model.

The cocoa powder export model has F-value of 46.22 with an error rate of less than $0.01 \%$. This indicates that Indonesian cocoa powder export simultaneously with $100 \%$ confidence level influenced by cocoa butter price of the world, domestic cocoa butter price, 
cocoa butter export of competitor countries, rupiah exchange rate against US dollar, value added tax and the lagged export of cocoa powder.

There are several exogenous variables similar in the model with some previous research ie world prices and exchange rates, but the results obtained are different. The results of Kiong W.S. et al (2010), Faustino B. (2011) and Verter N. (2016) stated that world black pepper price, world cocoa beans price and world coffee price affect export volume, while Abdel A. A. et al (2009), Nwachukwu I.N. et al (2010), Verter N. (2016) and Faustino B. (2011) in their research stated that the exchange rate affects the volume of export. The results of this study indicate that the world price of cocoa paste, cocoa butter and cocoa powder and exchange rate have no effect on export volume, but the tax policy in the form of value added tax and cocoa beans export duty and The lagged export of processed cocoa have significant effect on intermediate processed cocoa export. Arsyad M. (2007) in his study advised not to give export duty on cocoa beans because harming cocoa farmers. Arsyad $\mathrm{M}$. et al in his research in 2011 stated that the export tax policy negatively impacted the decline of cocoa beans export.

Arsyad's research is different from this research. The results of this study provide a positive sign of coefficient on cocoa beans export duty. It means that the export duty of cocoa beans is significant for the sustainability of intermediate processed cocoa production. The negative sign on the dummy coefficient of value added tax means that without it, cacao paste export will increase, due to a decrease in operational costs of the production process. Value added tax is charged to cocoa paste because it is the first intermediate processed cocoa product produced from cocoa bean processing.

Table 4 - RCA of Cocoa Paste, Cocoa Butter and Cocoa Powder

\begin{tabular}{|c|c|c|c|}
\hline Tahun & RCA Cocoa Paste & RCA Cocoa Butter & RCA Cocoa Powder \\
\hline 2005 & 1.319 & 90.835 & 3.596 \\
\hline 2006 & 1.306 & 96.952 & 3.745 \\
\hline 2007 & 1.393 & 105.792 & 3.442 \\
\hline 2008 & 1.828 & 102.903 & 3.392 \\
\hline 2009 & 1.279 & 93.570 & 3.227 \\
\hline 2010 & 3.204 & 102.289 & 3.559 \\
\hline 2011 & 6.097 & 95.568 & 3.891 \\
\hline 2012 & 7.838 & 121.474 & 4.733 \\
\hline 2013 & 7.134 & 108.364 & 4.273 \\
\hline 2014 & 8.012 & 115.330 & 5.259 \\
\hline 2015 & 9.869 & 125.305 & 6.907 \\
\hline
\end{tabular}

Source: Secondary data analysis from Trademap.

The quantity of Indonesian intermediate processed cocoa competitiveness can be measured using Balassa Index which emphasizes measurement on actual export value. The actual export flow represents a strong sector of a country known as the Revealed Comparative Advantage. Using Balassa index, its sobtained the competitiveness value of cocoa paste, cocoa butter and cocoa powder as can be seen in table 4.

Based on table 4, Cocoa Paste, Cocoa Butter and Cocoa Powder has an index value greater than one. It means that these products have a comparative advantage and can compete in the world market. Cocoa butter has a comparative advantage or greater competitiveness than cocoa paste and powder. It's because the price of cocoa butter is higher than the price of the other processed cocoa. As well as cocoa paste export, cocoa butter and cocoa powder, after the enactment of cocoa beans export duty policy in 2010, the competitiveness value of these intermediate processed cocoa products showed an increase. Thus, in order to increase cocoa paste, cocoa butter and cocoa powder competitiveness in the world market, it is necessary to increase the export of these products. With the increasing competitiveness of these intermediate processed cocoa products in Indonesia, Indonesia's opportunity to be an important country in the intermediate processed cocoa market is getting bigger. 


\section{CONCLUSION}

Based on results and discussion, it is concluded that cocoa butter and cocoa powder exports are significantly influenced respectively by cocoa beans export duty and the lagged export of its cocoa, while cocoa paste is significantly influenced by value added tax, cocoa beans export duty and the lagged export of cocoa paste. The policy setting by the government greatly influences the strength of intermediate processed cocoa export. The export restriction of cocoa beans is very important to increase the export volume of cocoa paste, cocoa butter and cocoa powder. Similarly, the policy of value added tax that greatly affects the cost of production to produce cocoa paste. The elimination of value added tax will further increase the export volume of cocoa paste. The increased export of the cocoa paste, cocoa butter and cocoa powder make cocoa Paste, cocoa butter and cocoa powder have a comparative advantage which is better in the world market.

\section{REFERENCES}

1. Akbar Faisal, 2015. Trade Policy Analysis of Indonesia Cocoa Industry, National Chung Hsing University, Department of Applied Economics, https://www.researchgate.net.

2. Chileshe Moses, 2005. Factors Affecting Coffee Exports in Zambia, University of Zambia.

3. Coffee and Cocoa Research Center, 2016. Jember, Indonesia

4. Directorate General of Plantation, 2014. Statistik Perkebunan Indonesia, Kakao 20132015, ditjenbun.pertanian.go.id.

5. FAO, Food and Agriculture Organization of the United Nations, www.fao.org.

6. Hameed Abdel Amna Awad, Hasanov Akram et al (2009), Supply and Demand Model for the Malaysian Cocoa Market, MPRA Paper No. 19568, posted 25, http://mpra.ub.unimuenchen.de

7. Kagochi J.M, 2007. Evaluating the Competitiveness of US Agricultural Market Commodities, Auburn University, Alabama.

8. Kiong Wong Swee, Khalid Abdul Rahim, Mad Nasir Shamsudin. (2010). Global Economy and Finance Journal Vol. 3 No. 1 March 2010, Pp. 78-87 Long-run Determinants of Export Supply of Sarawak Black and White Pepper: An ARDL Approach, http://www.wbiaus.org.

9. Ministry of Finance, 2012. Kajian Perkembangan Perekonomian Kakao Indonesia Pasca Pengenaan Bea Keluar Biji Kakao, http://www.fiskal.depkeu.go.id

10. Nwachukwu Ifeanyi Ndubuto, Nnanna Agwu, Jude Nwaru and George Imonikhe, 2010. Competitiveness and Determinants of Cocoa Export from Nigeria, Report and Opinion ISSN: 1553-9873,2(7): 51-54, http://www.sciencepub.net

11. Nwachukwu Ifeanyi Ndubuto et al, 2014. Competitiveness in The Export Demand for Nigerian Rubber. The Journal of Agricultural Sciences, 2014, vol.9, no 1: 1-12 https://www.researchgate.net

12. Salvatore, Dominick. 2014. Ekonomi Internasional. Jakarta Selatan: Salemba Empat

13. Trademap. Trade Statistics for International Business Development, http://www.trademap.org.

14. UNComtrade. United Nations Comtrade Database - International Trade Statistics https://comtrade.un.org/

15. Verter Nahanga, 2016. Cocoa export performance in the world's largest producer. Bulg. J. Agric. Sci, 22: 713-721 